\title{
IAMJ
}

INTERNATIONAL

AYURVEDIC

MEDICAL JOURNAL

\section{TENSION HEADACHE DURING THE PANDEMIC PERIOD AN AYURVEDIC OVERVIEW}

\author{
$\underline{\text { Harikrishnan. N. Menon }}{ }^{1}, \underline{\text { S M Pasha }}^{2}$ \\ ${ }^{1} \mathrm{PG}$ Scholar, ${ }^{2}$ Associate professor \& H.O.D, \\ Department of PG Studies in Shalakya Tantra, Government Ayurveda Medical College, Bangalore-560009, \\ Karnataka, India
}

Corresponding Author: nandakumarmenon56@gmail.com

\section{https://doi.org/10.46607/iamj4308102020}

(Published online: October 2020)

Open Access

(C) International Ayurvedic Medical Journal, India 2020

Article Received: 25/09/2020 - Peer Reviewed: 02/10/2020 - Accepted for Publication: 04/10/2020

Check for updates

\begin{abstract}
World is going through a period of pandemic and has been hit by economic recession, thus leading to people losing their jobs and the way of their livelihood has come to a halt. Leading to mental frustration in turn leading to a growth in tension headache cases. Thus, headache or cephalgia is the symptom of pain anywhere in the region of head, neck or scalp. Among the different types of headache, tension type of headache is most commonly seen neglected and difficult to treat. The modern treatment is restricted towards symptomatic relief and no permanent cure. It is characterized by pain, which is typically pressing or tightening in quality, mild to moderate in intensity and bilateral in nature, which can be correlated with Vataja Shirashoola. This paper investigates how pandemic has affected the tension headache and how can we prevent and manage it by Ayurveda.
\end{abstract}

Keywords: Tension headache, Vataja Shirashoola, pandemic

\section{INTRODUCTION}

Tension Types of Headaches (TTH) are recurrent episodes of headache which last minutes to weeks. It is the most common type of primary headache. The agestandardized 1-year prevalence of TTH was $35.1 \%$, 
higher among younger people ${ }^{1}$. During this pandemic of COVID-19 there is an increase in the number of stress headache or tension headache, for which one of the reasons is not being sure of what is coming, which can trigger headaches, anxiety and stress. Tension type of headache (ICD code-G44 209) is one of the common reasons for visits to primary care physicians and medical care providers. According to $\mathrm{WHO}, 70 \%$ of population suffer from tension headache, main symptoms are pain radiating from the lower back of the head, neck, eyes or other muscles groups in the body typically affecting both sides of the head. The pain is usually described as dull, pressure like, constricting or given a sense of fullness in the head. Patients describe it as like wearing a tight hat or a tight band around the head. Physical activity has no influence on headache intensity. No symptoms such as vomiting or nausea but may be present with photophobia and phonophobia. Mostly it is reported to start at some time during day and to increase slowly, although some people may have an aggravation by late evening ${ }^{2}$. The aggravating factors of TTH are stress, lack of sleep and not eating on time, these factors are mainly related to once lifestyle $^{3}$. During the pandemic and as a part of lockdown most people are working from home and many people are losing their jobs, thus people are suffering from everyday anxiety and increased stress levels and there is a drastic change in their routine of day to day life, like irregular sleep, change in the time and quantity of food, change in the surroundings which they are not usually exposed, over work stress, increased intake of caffeine and alcohol which all are triggering factors for tension headache ${ }^{4}$. These factors are not given importance and are not looked into. Ayurveda is a science which has given importance to dinacharya or lifestyle which helps in maintenance of manasika arogya which in turn helps in physical health. The symptoms of Tension type of headache can be correlated with Vataja shirashoola. In Ayurveda classics shirashoola is having primary importance among other shirorogas. Manasika nidana like bhaya, trasa, shoka aggravates the Vataja shirashoola 5 as considering the bhoomidesha for the vyadhi a young and thriving nation like India where professionals and employees who are working with stress and strain are more prone to tension type of headache especially in such a pandemic situation.

Charaka has defined Vataja shira shoola as severe pain in head, temples between eyebrows, dizziness, stiffness in neck, dissonance in ear and feeling like gauging of eyes and relieves on hot and unctuous things ${ }^{6}$. Sushrutha told it increases at night/evening and decreases by bandaging a tight cloth over head ${ }^{7}$. Vagbhata added sensitivity to light $^{8}$. Samprapthi gataka is given in figure no: $1^{9}$.

\section{Application of Ayurveda in management of tension headache}

The aim of this paper is to evaluate the various scope of Ayurveda in prevention and treatment of TTH during this pandemic and which can be used as a reference in future for decreasing the cases of TTH in society and make them aware about the situation they are going through. This can be done by following Ayurveda and Yoga. This is cost effective and viable. In modern medical science the treatment is mainly symptomatic and only gives temporary relief. The administration of analgesics and anti-depressants for a long time will lead to serious side effects. Here the main focus is treatments which can be done at home or which is easy for the person to carry out, keeping in mind the current pandemic situation.

\section{Steps of treatment include:}

1) Dinacharya or lifestyle:

- Waking up early in the morning "brahme muhoorthe uthishtet" 10

- Sleeping early at night and on correct time, minimum 7 hours of sleep

2) Ahara:

- Avoiding intake of rooksha ahara like fried items, chocolates, alcohol, tobacco, caffeine, junk foods.

- Intake of Vata hara ahara like adding milk, ghee into the diet ${ }^{11}$

3) Vataja shirashoola chikitsa: It includes snehana, swedana, Vatahara vihara and nasya. Susrutha and Vagbhata suggested Vata Vyadhi chikitsa and Nasya. Chakradatta suggested shiro vasti ${ }^{12}$, out of which we can adopt the following methods 
a) Abhyanga: With Narayana Taila, Ksheerabala Taila

b) Sneha paana: with Varunadi Ghritha or with milk and ghee at night

c) Swedana: Upanaha sweda by hot application of paste of Agaru

d) Virechana: Trivruth lehya

e) Nasya: With Anu Taila or Shad Bindu Taila

f) Yogas to be taken orally: Chitrakadi Vati, Vaishwanara Choornam

g) Shiro Pichu: The procedure like shiropichu can be even performed in the surrounding of a house hold also $^{13}$. But treatment modalities which are prescribed in Vataja shirashoola like Shiro vasti and Shiro dhara will be difficult to perform in a household condition as it requires a physician's supervision.

4) Application of Yoga: Yoga is considered as a noble way to handle stress. Stress is a general word, termed to various mental and bodily pressures experienced by people throughout life. Practicing yoga is considered as natural stress relief. Yoga is a mind body practice that combines stretching exercises, controlled breathing and relaxation. By practicing different types of pranayama like Bhastrika, Kapalbati, Bahya pranayama, Bhramari and practicing asanas like Uttanasan, Paschimottasan, Adhomukasana, Shavasana will help in relief of stress and in turn relief from $\mathrm{TTH}^{14}$.

\section{DISCUSSION}

\section{Probable mode of action of treatment:}

* Pathyahara vihara: As we are treating it as Vataja shirashoola, here we are including ghee and milk in diet which act as brahmana and Vata hara. More about what should be taken and what should not be is shown in Table no:2

* Vihara: Activities which does not increase stress or Vata should be followed, as shown in Table no: $3^{15}$

* Abhyanga: Is Vatahara, Puhstida, Nidrajanaka, sramahara. It acts on skin, as it is the site of Vata. Oil applied directly to skin mitigates Vata $^{16}$.

* Sneha Pana: Varunadi Ghrita does Srotho Shudi as well as Vata Anulamana.
* Upanaha sweda: Agaru due to its ushna property it acts against the sheeta property of Vata and help in mitigating shirashoola.

* Virechana: Is indicated as it does detoxification of body and it maintains the normal pathway of Prana and Udana vayu in body and does Vata anulomana $^{17}$.

* Nasya: Here due to Vata prakopa, Bruhmana nasya is indicated, as it is said in the classics 'Nasa hi shiraso dwaram'. The drug administered through nostril reaches shringataka sira marma and reaches murdha and eliminates morbid doshas and helps in nourishment ${ }^{18}$.

* Orally: "Roga Sarve Api Mandagni Jayate"19. Thus, the root cause of all disease is mandagni or improper digestion. We have to treat the agni and bring it to normalcy by means of giving deepana and pachana drugs or the drug which act as both. After the agni become sama, we have to administer Vata anulomana drugs, which result in proper movement of Apana Vayu, Resulting in alleviation of disease. The properties of drugs are shown in Table no: 1 .

* Shiro pichu: controls pacifies and expels the morbid Vayu, it has relaxing and coolant effect on the brain and nervous system and hence releases stress and anxiety, the master gland pituitary and the hypothalamus are relaxed by it and the circulation and nutrients take place in a proper way. TTH caused by sustained contraction of skeletal muscle gets relieved by physical effect of Shiro pichu. During Shiro pichu the absorption of substance takes place very well as it has more duration of contact and skin over scalp is thin ${ }^{20}$.

Yoga: Practice of Yoga helps in stress headache. According to Patanjali Yogasutra 'it is restraint of the activities of the mind'. Bhagavat Gita says it is the evenness of mind. In Yoga breathing using diaphragm can stimulate Vagus nerve, it is the main parasympathetic nerve extends from the medulla through the diaphragm to abdomen and responsible for slowing respiration, reducing heart rate, lowering blood pressure, stimulating digestive activity, thus it gives relief from stress and 
help in preventing or treating of tension type of headache $^{21}$. Another important aspect leading to Vataja shirashoola is controlling of urges or adharaniya vegas, one should not control their natural urges as it causes increase in Vata. 'Swasthasya Swastya Rakshanam'22 As Ayurveda says prevention is better than cure. By following proper diet, lifestyle we can manage the occurrence of tension type of headaches which is the most prevalent type of headache, especially which is seemed to be increased during the time of this pandemic. Due to lockdown effect most people have changed their lifestyle into a more sedentary one. Thus, by making them aware about its consequences and guiding them properly, we can manage it.

\section{CONCLUSION}

Ayurveda one of the most ancient sciences has given so much importance to lifestyle, stating that medicine only plays half of the role in treatment of a disease and other half is managed by ahara \& vihara. This statement has a great value in the current society, which has been hit by one of the worst pandemic that this world has seen. Tension types of headaches are one of such cases which have seen an increase in number during this period. Thus, by taking it as Vataja Shirashoola and treating it by means of its Chikitsa sutra we can manage it. Ayurveda as well as Yoga helps to guide an individual to lead a proper lifestyle and diet pattern by which he will be relieved from the stress created in day to day life. Thus, by nullifying stress through Ayurveda we can manage tension type of headache in cost effective and a viable way.

\section{REFERENCES}

1. Chowdhury. D. Tension type headache. annals of Indian Academy of Neurology.2012.Aug:24:15(5): http://www.annalsofian.org/text.asp?2012/15/5/83/100023

2. Kulkarni G, Rao.G, Steiner. T. Headache disorders and public ill health in India Prevalence estimate in Karnataka State. 2015. july: 22: 16(67): https://doi.org/10.1186/s10194-015-0549-x

3. [Cited 2020 September $10^{\text {th }} 12: 00 \mathrm{pm}$ ]. Available fromhttps://www.nhs.uk/conditions/tension-headaches/
4. White D. Have a headache? doctors say more people are experiencing them during pandemic. The Kansas city star.2020.23. https://www.kansascity.com/news/coronavirus/article244431272.html

5. Tripathi Brahmanand Agneevesha. Charaka. Dridhabala. Charaka Samhitha. Sutra Sthana. (17/17).Varanasi. Chaukambha Subharati Prakashan:2014.pp313

6. Tripathi Brahmanand Agneevesha. Charaka.Dridhabala. Charaka Samhitha. Sutra Sthana. (17/18).Varanasi. Chaukambha Subharati Prakashan:2014.pp313

7. Susrutha. Susrutha Samhitha English translation by prof. K. R. Srikantha Murthy. Publisher Chaukambha Orientalia Varanasi.Vol-3 First edition 2002(25/5).p133

8. Vagbhata. Ashtanga Hrdaya.Uttara sthana. Siroroga Vijnaniya.23/7.Aruna Datta. Reprint 2010.Chaukambha Orientalia.Varanasi.pp858

9. Tripathi Brahmanand Agneevesha. Charaka. Dridhabala. Charaka Samhitha.Sutra Sthana. (17/17).Varanasi. Chaukambha Subharati Prakashan:2014.pp313

10. Vagbhata. Ashtanga Hrdaya English translation by R. Vaidyanath. Publisher Chaukambha Orientalia Varanasi.Vol-1 First edition.2013(2/1). pp26

11. Tripathi Brahmanand Agneevesha. Charaka. Dridhabala. Charaka Samhitha Chikitsa Sthana.(26/150).Varanasi. Chaukambha Subharati Prakashan:2014.pp896

12. Dingari L.The Shalakya Tantra. Shiro roga. $2^{\text {nd }}$ ed. Varanasi. Chaukamba Orientalia.2005.pp14

13. Dingari L. The Shalakya Tantra. Shiro roga. $2^{\text {nd }}$ ed.Varanasi.Chaukamba Orientalia.2005.pp15

14. Kim S. R N. Effects of yoga exercises for headaches; a systematic review of randomized controlled trials. Journal of Physical Therapy Science.2015.Jul:22:27(7).

15. Acharya Jadavji Trikamji. Charaka Samhitha. Agnivesha. Chakrapani Datta's Ayurveda Deepika (sans), $1^{\text {st }}$ ed. Sutra sthana. Chaukhambha Sanskrit series office.Varanasi.2006.pp133-147

16. Agnivesha. Charaka Samhitha with Ayurveda Deepika commentary. R. K. Sharma. Bagwan Dash. $2^{\text {nd }}$ ed.Sutra sthana.5/87. Chaukhambha Sanskrit series office. Varanasi. 2001. pp124

17. Dingari L. The Shalakya Tantra. Shiro roga. $2^{\text {nd }}$ ed. Varanasi. Chaukamba Orientalia. 2005. pp15

18. Taywade H. Kulkarni S.Review of Naya karma and its mode of action. Interntional Journal of Research in Indian Medicine.2017.Sep.22.1(4)

19. Vagbhata. Ashtanga Hrdaya. Nidana sthana. Udara nidana.12/1.Aruna datta. Reprint 2010.Chaukambha Surabharathi Prakashan.Varanasi.pp513 
20. Raj K.A Conceptual Study of Shiro Pichu in the Management of Shirashoola. International Ayurvedic Medical Journal.2017.May:5(5)

21. Kisan R. Sujan M U. Satyaprabha TN. Effect of Yoga on Migraine: A comprehensive study using clinical profile and cardiac autonomic functions. International Journal of Yoga.2014.Dec:7(2)
22. Acharya Jadavji Trikamji. Charaka Samhitha. Agnivesha. Chakrapani Datta's Ayurveda Deepika (sans), $1^{\text {st }}$ ed. Sutra sthana. Arthe Dasha Mahamooliya. 30/26. Chaukhambha Sanskrit series office.Varanasi.2006.pp187

Table 1:

\begin{tabular}{|l|l|l|}
\hline SI No & Medicine name & Pharmacological effect \\
\hline 1 & Chitrakadi vati & Deepana, Pachana, Rochana, Grahi, Shulahara. \\
\hline 2 & Vaiswanara choorna & Vatanulomana, sula hara, Vedanasamana, Vibandha hara, Deepana, Pachana \\
\hline
\end{tabular}

Table 2: Pathya and apathya

\begin{tabular}{|c|c|c|}
\hline Sl no: & Do's & Don't's \\
\hline 1) & Snigdha Ushna, Guru, Ahara & Rooksha, Sheeta, Laghu Ahara \\
\hline 2) & Ahara With Madhura, Amla, Lavana Rasa Predominant & Ahara With Katu, Thiktha.Kashaya Rasa Predominent \\
\hline 3) & Shaali Varga: Raktha Shaali, Shashtika, Godhuma & Shaali Varga: Chinnaruda, Yava \\
\hline 4) & Shimbi Dhaanya: Kulatha, Masha, Tila, Sarshapa & Shimbi Dhaanya: Mudga, Raja Masha, Chanaka \\
\hline 5) & Mamsa Varga: Anupa Mamsa, Matsya, Kukkuta, Mahisha & Mamsa Varga: Jangala Mamsa \\
\hline 6) & Shaaka Varga: Kushmanda, Changeri, Bimbi & $\begin{array}{l}\text { Shaaka Varga: Patola, Karavellaka, Surana, Palakya, } \\
\text { Thanduliya }\end{array}$ \\
\hline 7) & $\begin{array}{l}\text { Phala Varga: Pakva Amraphala, Panasa, Pakwa Ppitha, Dad- } \\
\text { ima, Narangaadali, Narikela, }\end{array}$ & Phala Varga: Bala Amraphala, Pakva Vrkshamla \\
\hline 8) & $\begin{array}{l}\text { Harita Varga: Ardraka, Jambira, Balamulaka, Dhanyaka, Pal- } \\
\text { andu, Lasuna }\end{array}$ & Harita Varga: Shigru \\
\hline 9) & $\begin{array}{l}\text { Gorasa Varga: Gavya Paya, Avi Ksheera, Dadhi, Takra, } \\
\text { Navneeta, Go Ghritha }\end{array}$ & Gorasa Varga: Mahisha Ksheera, Apakwa Dugdha \\
\hline 10) & Ikshu Varga: Ikshu, Guda, Sita, Khanda Sharkara & Ikshu Varga: Madhu \\
\hline 11) & $\begin{array}{l}\text { Kritanna Varga: Manda, Peya, Vilepi, Mamsa Rrasa, Payasa, } \\
\text { Rasala, Kullatha Yoosha }\end{array}$ & Krittanna Varga: Mudga Yoosha, Laja, Yava Rotika \\
\hline 12) & $\begin{array}{l}\text { Ahara Varga: Tila Tila, Eranda Taila, Pipali, Maricha, Hingu, } \\
\text { Saindhava }\end{array}$ & Ahara Varga:Kshara \\
\hline
\end{tabular}

Table 3: Avoidance of following Vihara

- Vega dharana: Shakrt, Mutra, Jrmbha, Chardi, Kshavathu, Bashpa

- Ati vyayama

- Ratrijagarana

- Ati vyavaya

- Diwaswapna

- Manasika factors like: Chinta, Bhaya, Krodha, Shoka 
Figures

Figure 1: Samprapthi of Vataja shirashoola:

Nidana-Aharaja, Viha-
raja and Manasika

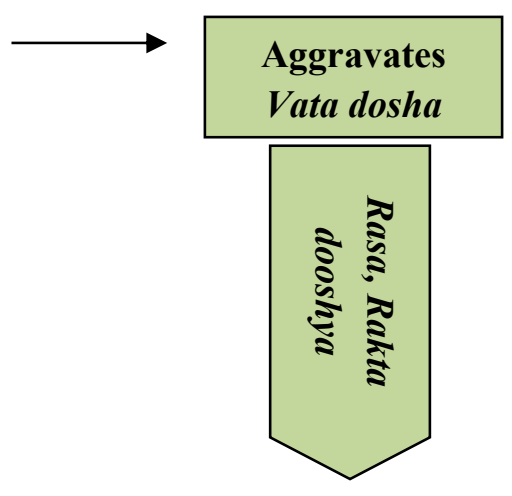

Enters Shiras- Vyadhi

Adhishtana

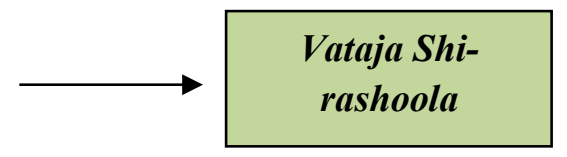

\section{Source of Support: Nil}

\section{Conflict of Interest: None Declared}

How to cite this URL: Harikrishnan. N. Menon \& S M Pasha: Tension Headache During The Pandemic Period An Ayurvedic Overview. International Ayurvedic Medical Journal \{online\} 2020 \{cited October, 2020\} Available from: http://www.iamj.in/posts/images/upload/4835_4840.pdf 